Rothstein, A. T. V., 1963. Remarks in discussion on paper by D. R. Bowes and R. G. Park. Proc. geol. Soc. Lond., 1608, 85-6.

Stewart, F. H., 1947. The Gabbroic Complex of Belhelvie in Aberdeenshire. Quart. Jour. geol. Soc. Lond., 102, 465-498.

DEPARTMENT OF BIOLOGY AND GEOLOGY,

A. T. V. RothstenN.

NorwoOd TeCHNICAL COLlege,

KNIGHTS HiLl,

LoNDON, S.E. 27.

15th March, 1964.

\title{
TONSTEIN BAND IN THE SOUTH LANCASHIRE COALFIELD
}

SiRS,- R. A. Eden et al. ${ }^{1}$ refer to the discovery of several tonstein bands in the coalfields of the East Midlands. In May 1961, a 1 inch tonstein band was discovered in the upper part of the Worsley Four Feet Seam at Agecroft Colliery, Lancashire, in the course of work on the petrology of coal seams and associated measures, at the Chester Coal Survey Laboratory (now operating from Shade House, Pendlebury).

Macroscopically, the band had been recorded as an inferior dull coal. However, on microscopical examination, with oil immersion objectives, of stained polished blocks, vermicules of kaolinite, displaying the characteristic "cat's tail "structure, were clearly visible. A considerable amount of carbonaceous matter was also present, the ash content of the band being 46 per cent.

Thin sections were prepared at the Sheffield Coal Survey Laboratory and it was confirmed that the band was indeed a tonstein, containing lenses of microcrystalline kaolinite in addition to the vermicules.

Examination of crushed samples of the seam from the nearby Astley Green Colliery also indicated the presence of the band at the same horizon. This band may be the equivalent of that recorded in the High Main Seam of the East Midlands.

Central. Laboratory,

H. Mayland.

NORTH WESTERN Division,

National Coal. BoARd

PENDIEBURY, LANCS.

April, 1964.

1 Eden, R. A., R. W. Elliott, R. E. Elliott, and B. R. Young, Tonstein Bands in the Coalfields of the East Midlands. Geol. Mag., 1963, 100, 47-58.

\section{THECOSMILIA KAMBENSIS NOM. NOV. FOR T. MAGNA GREGORY SP. NON ÉTALLON}

SiR,-J. W. Gregory described a coral from the Kambe Limestone of Kenya as Aplophyllia magna (Monog. geol. Dept. Hunter. Mus., 4, (10), 1930, p. 204, pl. 19, figs. 3a, b), which in 1963 (Overseas Geol. Min. Resources, 9, (1), p. 36, pl. 3, fig. 4) I showed should be referred to Thecosmilia Edwards and Haime. I am indebted to Prof. O. F. Geyer, of Stuttgart, for pointing out to me that T. magna (Gregory) is thus a junior homonym of Thecosmilia magna Etallon (in Thurmann, J. and Etallon, A., Leth. bruntr., 1864, p. 385, pl. 54, fig. 11 ; see also Koby, F., Monographie des polypiers jurassiques de la Suisse, Mém. Soc. paléont. Suisse, 11, (4), 1884, p. 166, pl. 44, figs. 1-3, and Geyer, O. F., Paläont. Zeitsch., 29, (3/4), 1955, p. 119). I therefore propose the name Thecosmilia kambensis for T. magna Gregory sp. non Etallon. 